\title{
As REGRAS DE CIVILIDADE PRESCRITAS PELAS LIGAS DA BONDADE NAS ESCOLAS PÚBLICAS ESTADUAIS DO SUL de Santa Catarina (1953-1970)

\author{
RULES OF CIVILITY PRESCRIBED BY LEAGUES
} \\ OF KINDNESS IN PUBLIC SCHOOLS OF THE STATE SOUTH of Santa Catarina (1953-1970)
}

\begin{abstract}
Mariane Rocha Niehues
Mestranda em Educação pela Universidade do Extremo Sul Catarinense (Unesc), Criciúma,SC. Coordenadora de Ensino na Prefeitura Municipal de Forquilhinha, Forquilhinha, SC. Membro do Grupo de Pesquisa História e Memória da Educação (Grupehme). mariane1709@gmail.com

Giani Rabelo

Doutora em Educação. Professora do programa de pós-graduaçăo em educaçăo e do curso de pedagogia da Universidade do Extremo Sul Catarinense (Unesc), Criciúma, SC. Líder do Grupo de Pesquisa História e Memória da Educação (Grupehme), cadastrado no CNPq.
\end{abstract}

gra@unesc.net

\begin{abstract}
Resumo: O presente artigo é resultado de uma pesquisa que buscou perceber quais as regras de civilidade as Ligas da Bondade, implantadas nas escolas públicas estaduais do sul de Santa Catarina, prescreviam aos(às) alunos(as) participantes entre os anos de 1953-1970, bem como compreender o que levou as escolas a implantarem as Ligas da Bondade. Com o intuito de aprofundar este estudo, foram estabelecidos alguns objetivos específicos: identificar o intuito com que foram criadas as Ligas da Bondade nas escolas públicas estaduais do sul de Santa Catarina; investigar sobre as atribuiçóes das Ligas da Bondade; entender como funcionavam as Ligas da Bondade; identificar quem eram os membros participantes das Ligas da Bondade. Foram analisados, por meio de uma pesquisa documental, os relatórios das Ligas da Bondade da EEB de Meleiro; em Criciúma, a EEB Professor Lapagesse; em Maracajá, a EEB Manoel Gomes Baltazar. Estes documentos encontram-se no banco de dados do Centro de Memória da Educação do Sul de Santa Catarina (virtual).
\end{abstract}

Palavras-chave: Liga da Bondade. Associaçóes auxiliares da escola. Regras de civilidade.

Aвstract: This article is the result of a study that sought to understand what the rules of civility the League of Kindness, implemented in public schools in southern Santa Catarina, prescribed to / the students / participants between the years 1953-1970, as well as understand what led schools deploy the League of Kindness. In order to deepen this study, we set out some specific objectives: identify the purpose for which they were cre- 
ated the League of Kindness in public schools in southern Santa Catarina; investigate the roles of the Leagues of Kindness, understand how they worked the League of Kindness; identify participants who were members of the Leagues of Kindness. Were analyzed by means of documentary research, reports Leagues of Kindness of Meleiro BSE; in Criciúma, the teacher Lapagesse BSE and in Maracajá Manoel Gomes Baltazar BSE. These documents are in the database of the Memorial Center for Education of Southern Santa Catarina (virtual).

KeYwOrds: League of Kindness. Auxiliary School Associations. Rules of civility.

\section{Introdução}

O Centro de Memória da Educação do Sul de Santa Catarina (virtual) (Cemessc) está em processo de implantação. Trata-se de um projeto aprovado pelo $\mathrm{CNPq}^{\mathrm{I}}$ que está sendo coordenado pelos membros do Grupo de Pesquisa História e Memória da Educação (Grupehme). O Cemessc conta com um acervo digital composto por imagens de prédios escolares, mobílias e objetos escolares, documentos escritos e iconográficos, considerados mais antigos e com relevante valor histórico. Fazem parte do Cemessc as escolas mais antigas da rede estadual dos municípios da regiấo sul de Santa Catarina, mais precisamente da Associação Municípios do Extremo Sul Catarinense (Amesc) (II) e da Associação de Municípios da Regiáo de Laguna (Amurel) (5).

No trabalho foram digitalizados documentos e fotografados objetos antigos e a arquitetura das escolas. Diante deste processo de coleta de dados foram encontradas atas e cadernos da Liga da Bondade das escolas: EEB Manoel Gomes Baltazar, de Maracajá, EEB de Meleiro, de Meleiro e EEB Professor Lapagesse, de Criciúma. Os referidos documentos são datados de 1953-1970. Enquanto fontes de pesquisa, estes documentos mostram açôes pedagógicas adotadas no espaço escolar e evidenciam algumas situaçôes do cotidiano escolar.

Tendo como objetivo geral perceber as regras de civilidade das Ligas da Bondade, bem como identificar o intuito com que foram criadas, realizamos uma pesquisa de campo do tipo documental. Para tanto, fez-se um levantamento dos registros existentes na época, bem como da legislação que a fundamentava. 
Os dados foram analisados a partir do conceito de processo civilizador e regras de civilidade proposto por Norbert Elias (1993). Para ele, civilização é um processo lento e demorado, relacionado aos padróes sociais e às açóes oscilantes da sociedade. Outra discussão central deste trabalho foi a questão da cultura escolar. De acordo com Silva (2009, p. I25), “[...] por cultura escolar, entende-se [...] o modo como a escola se institui, se organiza, se apropria de elementos da cultura, faz determinadas representaçóes dela, e produz práticas com vistas à formação humana”.

Os relatórios mostram açóes desenvolvidas pela Liga da Bondade, bem como seus interesses e finalidades, onde a propagaçáo dos símbolos é direcionada ao catolicismo, aos valores da moral cristá. Observa-se uma forte influência que a Igreja Católica mantinha sobre a escola. Certamente os(as) alunos(as) eram vistos(as) como ferramentas para alcançar a família, fazendo com que os pais estivessem também em contato com a Igreja, pois se as crianças estivessem envolvidas, logicamente seus pais também estariam.

\section{Associaçóes auxiliares da escola no processo de nacionalizaçáo do ensino no Estado Novo}

A Constituição de 1937 incentivava a Campanha de Nacionalização, onde as unidades federativas iniciaram a busca pela identidade nacional. Tal campanha visava dar características brasileiras às regióes colonizadas por imigrantes europeus, principalmente no sul do país. Para que a Campanha de Nacionalizaçáo se concretizasse, Zen (2007) afirma ter sido indispensável a reorganização dos elementos de divulgação cultural, para que transmitissem os ideais nacionalistas brasileiros. Assim, o governo passou a usar como forma de "abrasileiramento" dos imigrantes as associaçôes culturais, religiosas e o estabelecimento escolar.

De acordo com Martinson (2009), em Santa Catarina, a nova e ríspida política de nacionalizaçáo iniciou com o Decreto-Lei n. ${ }^{\circ} 88$, de março de 1938. Durante esta época de regime político autoritário, a educaçáo seguia orientaçôes de caráter centralizador, conduzida por uma legislação que buscava assegurar a unidade nacional. A proposta do governo modificava métodos de ensino, organização, administração escolar, constituição dos professores, permitindo o uso de materiais impressos e obrigando o 
uso do idioma português. Segundo Cunha (20I0), as associaçóes auxiliares da escola foram criadas seguindo disposiçóes nacionais e formavam grupos estabelecidos nas escolas primárias.

Entre as associaçóes auxiliares da escola estavam: a Liga Pró Língua Nacional, Caixa Escolar, Cooperativa Escolar, Clube Agrícola, Pelotão de Saúde, Biblioteca Escolar, Jornal Escolar, Clube de Leitura, Liga da Bondade, Círculo de Pais e Professores, Orfeão Escolar, Museus Escolares e Centros de Interesse. Estas associações constituíam

Grupos organizados no interior das instituições escolares fossem elas públicas ou particulares, com um propósito comum de integrar o corpo discente, estimulando uma formação cívica, moral e intelectual através do exercício de "atitudes de sociabilidade, responsabilidade e cooperaçáo", contribuindo igualmente com o processo de busca por uma identidade nacional (ZEN, 2007).

No entanto, antes mesmo do Decreto-Lei n. ${ }^{\circ}$ 88, de março de I938, Zen (2007) diz que várias organizaçóes já faziam parte do cotidiano escolar: jornais escolares, bibliotecas, caixas escolares, clubes agrícolas, entre outros. Ao que tudo indica, a Reforma Trindade ${ }^{2}$ apresentada pelo professor Luiz Sanches Bezerra da Trindade, em Santa Catarina, em I935, já visava criar e manter entidades desse gênero, porém não designadas de associaçôes auxiliares da escola.

A impregnação destes valores nos faz pensar sobre a intencionalidade, formar alunos(as) para serem cidadãos responsáveis, cooperativos e participantes na perspectiva e princípios da Escola Nova e pelas diretrizes de nacionalização, fortemente introduzidas no Estado Novo.

Embora os Decretos, Leis e Circulares ensinassem como organizar e manter as associaçóes auxiliares da escola, a existência de todas não era obrigatória dentro de um mesmo educandário. No entanto, o Decreto-Lei n. ${ }^{\circ} 88$, de 3 I de março de 1938 ,

[...] determina em seu artigo $17^{\circ}$ que o Diretor ou os Professores poderiam ser afastados caso não adotassem os programas oficiais para o curso primário nos quais estavam descritos as dire- 
trizes para o funcionamento das Associações (RAMOS, 1938 apud ZEN, 2007, p. 56).

Com o "início do fim" do Estado Novo em 1944, Zen (2007) nos fala que surgem novas instruçooes para as referidas associações. O DecretoLei n. ${ }^{\circ}$ 2.991, de 28 de abril de 1944, vem para confirmar isso, investigando os pormenores do funcionamento de dez das associaçóes auxiliares da escola. O documento assinado pelo diretor do Departamento da Educação, Sr. Elpídio Barbosa, traz indícios que revelam a precisão de formar o cidadáo para o mundo moderno e urbano.

Em 1946, as associaçôes auxiliares da escola passam novamente a ganhar novos rumos. Renovava-se o direito do Estado reger a graduaçáo cívica e moral da populaçáo, manifestado no projeto de constituiçáo de um ensino de aspecto nacional. Isso ocorreu por meio da publicação oficial do regulamento para os estabelecimentos de ensino primário, estabelecido pelo Decreto-Lei n. ${ }^{\circ}$ 3.735, de 17 de dezembro de 1946, que apresentava instruções para organização dessas associações (CUNHA, 20Io). Este novo decreto definiu que os estabelecimentos de ensino primário deveriam promover, entre os alunos, a organização e o desenvolvimento de atividades educativas.

De acordo com Zen (2007), os decretos de 1944 e de 1946 estavam em uniformidade, pois apresentavam as mesmas regras às associaçóes; no entanto, houve "[...] inserçóes ou alteraçóes de termos que mudam significamente a proposta de uma ou outra Associação [...]" (ZEN, 2007, p. 6I). Neste sentido, o Decreto-Lei n. ${ }^{\circ}$ 3.735, de 17 de dezembro de 1946, seria uma reformulação do Decreto-Lei n. ${ }^{\circ}$ 2.99I, de 28 de abril de 1944.

Posteriormente, em I2 de dezembro de 1947, o secretário da Justiça, Educação e Saúde cria, por meio da Lei n. ${ }^{\circ}$ 40, o cargo, no Quadro Único do Estado, de inspetor das associaçóes. Os inspetores desempenharam função estratégica, realizando um papel fundamental neste processo. Estes orientavam, aplicavam puniçóes, fiscalizavam a escola, na matrícula, na frequência, nas provas, no plano de ensino, controlando e padronizando a escola pública de forma a garantir a centralização do ensino; ou seja, o papel do inspetor era mais de caráter administrativo do que pedagógico (MARTINSON, 2009). 
Cada associação auxiliar da escola deveria elaborar anualmente os relatórios de trabalho, constando um parecer descritivo detalhado sobre as atividades exercidas na escola, dispondo à Inspetoria de Ensino informaçóes que pudessem propiciar o cumprimento das legislaçôes em vigor. Estas informaçôes eram repassadas ao Ministério da Educação e Saúde.

As associaçóes procuravam desenvolver numerosas situações que os alunos poderiam vivenciar no cotidiano; estas não apenas desejavam educar intelectualmente, mas buscavam desenvolver novas condutas que se esperava de um cidadão brasileiro.

\section{A cultura escolar e a emergência da Liga da Bondade}

A partir dos anos de I990, o conceito de cultura escolar se fortaleceu. Com os mais variados focos de pesquisa, a escola tornou-se uma ferramenta de frequente estudo. Julia (200I) descreve a cultura escolar como um conjunto de normas que definem conhecimentos a ensinar e condutas a inculcar, um conjunto de práticas que permitem a transmissão desses conhecimentos e a incorporação desses comportamentos, normas e práticas coordenadas a finalidades que podem variar segundo as épocas.

Conforme Silva (2006), as bases para a compreensão da cultura escolar são os indivíduos e suas práticas. Deste modo, os meios de comunicação, os discursos e as linguagens encontrados no dia a dia escolar, compóem um aspecto essencial de sua cultura. Sendo assim, é possível afirmar que por meio dos registros da Liga da Bondade encontrados em cada um dos estabelecimentos-alvo deste estudo, pode ocorrer uma aproximação do(a) pesquisador(a) com a cultura escolar de cada educandário, uma vez que a cultura escolar também foi produzida pela Liga da Bondade ao prescrever regras de civilidade.

Segundo Lousada (2010), a primeira referência sobre a Liga da Bondade foi apresentada em I9I2, no Congresso de Educação Moral de La Haya. Em I9I7, as mesmas foram instituídas em Portugal, visando promover o "progresso moral e político da raça portuguesa", onde se almejava educar as crianças dos 5 aos 12 anos, no quadro da escola primária. Essa informação nos faz pensar se a Liga da Bondade não foi uma proposta 
trazida de Portugal para as escolas brasileiras, uma vez que em Portugal elas já existiam desde I9I7 e no Brasil elas começam a aparecer em período posterior a este.

Em Santa Catarina, isso ocorreu mais tarde. Segundo Beirith (2009), o ensino primário foi regulamentado no Estado de Santa Catarina em I7 de dezembro de 1946 em conformidade com a Lei Orgânica Federal, onde este regulamentava, entre outros aspectos, a estrutura e o funcionamento das associaçôes escolares e entre elas a Liga da Bondade.

A Liga da Bondade tinha como atribuição educar moralmente, fazendo motivar nas crianças a consciência do dever, a prática dos bons hábitos transformando em virtudes, estimular a ética dos alunos com base nos princípios, e que fossem educados pelo coração e utilizassem da sua alegria, confiança e fé, em consonância com os intuitos da civilidade. Para ingressar na Liga da Bondade, os alunos teriam que assumir o seguinte juramento:

Assumo o compromisso de me tornar ainda melhor aluno, melhor filho e melhor amigo dos meus colegas; a respeitar os mais velhos, a zelar pelos bens públicos e a proteger os animais. Se eu falhar nesses propósitos, aceito a punição que me for aplicada. (SANTA CATARINA, I947, p. IOo).

Para participar da referida associação, Cunha (20I0) diz que era necessário que seus integrantes fossem alunos perfeitamente bons, que servissem de modelo aos colegas. Deste modo, fica nítido que a civilidade expressa enobrece a dignidade e as perfeiçóes de cada pessoa, seja tanto por sua conduta e comportamento como por seu modo de agir. Neste caso, a bondade era determinada pelo julgamento e olhar alheio.

Era missão da escola capacitar e formar bons cidadãos, que com seriedade pudessem colaborar e cooperar na construção de uma sociedade melhor, ou seja, teriam a incumbência de semear "bons frutos", para que estes compreendessem a importância da referida liga e propagassem a bondade.

A partir dos documentos encontrados faço uma breve apresentaçáo das escolas e das Ligas da Bondade, de modo a relatar como se dava a organização dessa associação dentro de cada educandário. 


\section{I EEB Manoel Gomes Baltazar}

Fundada com a denominação de Escola Mista Desdobrada de Maracajá, em 1954, a pequena escola transformou-se em Escola Reunida Manoel Gomes Baltazar; em 1958 deu-se início à construção do Grupo Escolar. A nova escola foi inaugurada no dia 2 I de maio de 1959, pelo inspetor Otávio Munir Bacha, tendo como primeira diretora, a Irmã Leonis. Com o Decreto SEE n. ${ }^{\circ}$ 6.046, de I7/02/1967, o Grupo Escolar Manoel Gomes Baltazar passa a chamar-se Ginásio Normal Manoel Gomes Baltazar e, em 1970, transformou-se em Escola Básica, através do decreto SEE n. ${ }^{\circ}$ I0.485, de I7/02/I97I. A escola fica situada na Rua Pedro Rocha n. ${ }^{\circ}$ i I , no Centro de Maracajá (SC) (EEB MANOEL GOMES BALTAZAR, [I9--]).

No acervo desta escola foram encontrados cinco relatórios da Liga da Bondade datados de 1959-I969. A referida associação foi estabelecida no dia 20 de junho de 1959, sendo composta por docentes e discentes, a diretoria formada por presidente, secretária, monitores, professor(a) orientador(a), e ainda os(as) alunos(as) considerados(as) sócios(as).

A diretoria da Liga da Bondade organizava anualmente relatórios com o objetivo de mostrar à Irmá Leonis (diretora da escola) todas as atividades praticadas durante o ano letivo. Cada ano uma professora ficava responsável pelas atividades a serem desenvolvidas.

Durante o ano de 1959, ocorreram cinco reunióes, que "foram feitas com entusiasmo e interesse dos membros" (EEB MANOEL GOMES BALTAZAR, I959, p. 2). As reunióes do referido ano foram coordenadas pela orientadora Beatriz Machado e pela secretária Célia Nolla, com a presença da Irmã Leonis. No decorrer do mesmo ano, a partir da Campanha das Santas Missões e Natal dos Lázaros foram arrecadadas 4.28I boas ações e distribuídas entre as pessoas mais necessitadas.

No ano de 1963 aconteceram nove reunióes, sendo que seis com a presença da diretoria e as outras três somente entre os(as) sócios(as). As reuniôes deste ano foram coordenadas pela orientadora Mari Arlete Sandrini e a secretária Maria das Dores Jacinto, com a participação da diretora Irmã Leonis.

As mesmas campanhas organizadas no ano de 1959 foram realizadas e sobre isso ficou registrado que "[...] com muito entusiasmo da 
parte de alunos e professores foi feita a Campanha Missionária e Natal dos Lázaros" (EEB MANOEL GOMES BALTAZAR, 1963, p. 3). Neste ano, as crianças ainda conseguiram coletar fundos para comprarem os brinquedos a serem utilizados no recreio escolar.

No ano letivo de 1967 aconteceram nove reuniōes, sendo que na nona reuniāo foi lida a ata anterior e o relatório anual, sob orientação da professora Avetti Paladini Zilli. No balanço anual foi apresentado que a Liga da Bondade angariou 16,3 mil boas açóes; houve destaque sobre o auxílio mútuo entre os professores e alunos, merecendo destaque a atitude da professora Marília Machado que caridosamente levou uma criança ao médico. Foram também destacadas: a ajuda de alunos e professores para a merenda escolar, a colaboração em prol da Associação da Liga da Bondade por meio de rifas, teatros, a arrecadação para as Missóes, para o Natal dos Lázaros e para a escola. A professora D. Avetti destaca que "A bondade é uma das principais virtudes da pessoa" (EEB MANOEL GOMES BALTAZAR, 1967, p. 3).

Com a participação de todos da instituição ocorreu a última reunião da Liga da Bondade no ano de I968. Foi lida a ata anterior e o relatório das atividades anuais. Ao término da reuniāo, a professora Rutinaque finalizou agradecendo e destacando a importância de continuar cotidianamente servindo todas as pessoas como irmãos.

No ano de 1969, realizaram oito reunióes sendo que na última a professora orientadora Maria Elizabete Mastella salienta as boas açóes ocorridas no ano: a doação de material escolar e roupas para os mais necessitados, contribuiçóes para a merenda e festas, recolhimento de arrecadaçôes para as Missōes, campanha para o dia das mães com a realizaçáo de uma festa para homenageá-las, além da distribuição de doces no Dia da Criança.

\subsection{EEB de Meleiro}

No início, a escola era denominada Escola Reunida Virgínea Borges Coral, tendo sua fundação em or de agosto de 1949, pelo Decreto n. ${ }^{\circ} 809$. Porém, de acordo com o histórico escolar, esta mesma escola foi fundada através do Decreto n. ${ }^{\circ} 809$, do dia 27/05/1950, iniciando suas 
atividades no dia 27/09/1950. Mais tarde a escola mudou a denominação, passando a chamar-se Escola de Educação Básica de Meleiro. A escola fica situada na Rua Sete de Setembro, no Centro de Meleiro (SC). (EEB DE MELEIRO, [I9--]).

A associação Liga da Bondade da EEB de Meleiro foi fundada no dia Is de março de 1952. Época em que a cidade de Meleiro ainda era distrito do município de Turvo. Os registros da liga encontrados dizem respeito a quase duas décadas, entre os anos de 1953 a 1970, concentrados em uma única ata do período.

No início de cada ano era apresentado, pela orientadora da escola, o plano de trabalho da Liga da Bondade, onde nele continha o rol de todas as atividades que deveriam ser desenvolvidas. $\mathrm{Na}$ reunião de abertura das atividades de cada ano também eram dadas as instruçóes e orientaçóes sobre a Liga da Bondade.

A Liga da Bondade da EEB de Meleiro organizava anualmente de três a quatro reunióes, geralmente realizadas nos meses de março, junho, setembro e novembro, sendo que a coordenação da reunião ficava a cargo da secretária da Liga da Bondade do ano corrente.

Constituía-se como assunto central das primeiras reunióes a elaboração do plano anual de trabalho, para que todos os envolvidos estivessem a par de seus direitos e deveres.

a) Serão considerados sócios todos os alunos que satisfazerem as condiçóes exigidas, quando no ato da posse assumem o compromisso da Liga;

b) Os sócios que incorreram faltas serão punidos;

c) Os monitores terão um em cada classe, que estes terão uma caderneta no qual serão registrados os fatos do dia: como as boas açóes praticadas pelos colegas;

d) Será destinado um dos monitores para se encarregar da tesouraria, caso houver necessidade;

e) Serão feitas diversas campanhas como: a da garrafa, rifas, resultado este para o Natal dos Lázaros;

f) Serão feitos centros de interesse ou álbuns instrutivos. (EEB DE MELEIRO, I953-I970, p, 3). 
Fica evidente, frente à proposta de trabalho, um dos objetivos desta associação: que os(as) sócios(as) compreendessem o sentido e significado da importância da Liga da Bondade, para que fizessem propaganda junto aos colegas de modo que a Liga alcançasse suas metas.

Diversas eram as formas que os(as) sócios(as) poderiam desenvolver seu espírito solidário, seja na conservação dos móveis e das salas de aula da instituição ou nas campanhas desenvolvidas em prol dos alunos necessitados, para manutençáo da casa dos professores, para as Santas Missóes, Natal dos Lázaros, ou seja, de acordo com a necessidade que surgia.

Durante o ano de I968, a então presidente da associação, professora Júlia Maria Nazário, salientou:

Dignos são de elogios, todos os alunos que fizeram parte nesta associação, pois não mediram esforços em trabalhar na campanha dos lápis, dos agasalhos, das missōes, nos bons exemplos, na higiene da sala de aula, também se dedicaram para o bom comportamento, união entre os escolares e esforçando-se em prol do Natal dos Lázaros (EEB DE MELEIRO, 1953I970, p. 47).

Afinal, o objetivo da referida Liga da Bondade era fazer com que as crianças se tornassem melhores cidadãos, que respeitassem os mais velhos, zelassem pelos bens públicos e preservassem a natureza.

\subsection{EEB Professor Lapagesse}

A Escola de Educação Básica Professor Lapagesse está situada na Rua Marechal Floriano Peixoto n. ${ }^{\circ}$ 255, no Centro de Criciúma (SC). De acordo com o histórico do educandário, a mesma foi fundada em 15 de agosto de 1932, pelo Decreto n. ${ }^{\circ}$ 26I, de I5/08/1932, assinado pelo General Ptolomeu de Assis Brasil, na época, interventor federal de Santa Catarina. Porém, a escola foi inaugurada em $\mathrm{I}^{\circ}$ de março de 1933, pelo inspetor escolar João dos Santos Aivão e possuía quatro professores(as), um porteiro, além do diretor Sr. Silvio Berendt, para atender I8I alunos(as) matriculados(as) em cinco turmas de $\mathrm{I}^{\circ}$ a $4^{\circ}$ ano (EEB PROFESSOR LAPAGESSE, [I9--]). 
A Liga da Bondade no antigo Grupo Escolar, hoje EEB Professor Lapagesse foi fundada no dia is de maio de 1944. Os registros encontrados sobre esta associação escolar dizem respeito aos anos de 1962-1966.

Os(As) alunos(as) que almejassem serem sócios(as), além de possuírem bom comportamento, deveriam pagar mensalmente dois cruzeiros, dinheiro a ser revertido na compra do que fosse necessário para as pessoas mais necessitadas. Para acompanhar o desenvolvimento da Liga, havia em cada classe um monitor responsável por registrar em uma caderneta os fatos diários, juntamente com as boas ações praticadas pelos(as) sócios(as). De forma que quem não cumprisse com as normas seria punido.

No início de cada ano era apresentado, pela orientadora da escola, o plano de trabalho da Liga da Bondade, onde nele continha o planejamento das atividades a serem desenvolvidas durante o ano. Eram organizadas anualmente de sete a oito reuniôes, sendo que na última reunião do ano era apresentado o relatório das atividades consideradas relevantes.

Nessa ocasião também seus(suas) sócios(as) eram alertados sobre a necessidade da cooperação para que a Liga alcançasse suas finalidades, de modo que propagassem a Liga da Bondade e trouxessem novos membros. Para a escolha dos(as) sócios(as) era levado em consideração não apenas sua vida escolar, mas também o seu comportamento fora dela.

A Liga da Bondade foi uma das associaçóes auxiliares da escola que, talvez, mais tenha contribuído para a prescrição de regras de civilidade para aqueles(as) que estavam inseridos nas atividades e principalmente as campanhas dirigidas aos mais necessitados.

\section{As Ligas da Bondade prescrevendo regras de civilidade}

Para problematizar e analisar os registros da Liga da Bondade, partimos do conceito de processo civilizador de Norbert Elias (1993), onde ele diz que as sociedades, no decorrer da história, criaram princípios e valores com o intuito de orientar as relaçôes sociais. Desta forma, as boas maneiras estão intimamente atreladas a estes comportamentos sociais. Eles transcendem as regras de etiqueta, incluindo aqueles relacionados à moral, à ética, aos valores individuais e aos feitios externos, se estes não fossem adotados provocaria exclusão e desaprovação daqueles que não os seguissem. 
Para tanto, Chartier (I992, p. 220) diz que: “[...] nenhum texto existe fora do suporte que lhe confere legibilidade; qualquer compreensão de um texto, não importa de que tipo, depende das formas com as quais ele chega até seu leitor”. É com base nessa afirmação, que passamos a analisar as capas das atas que serviram como ferramentas importantes no processo de registro da história das associaçôes Liga da Bondade.

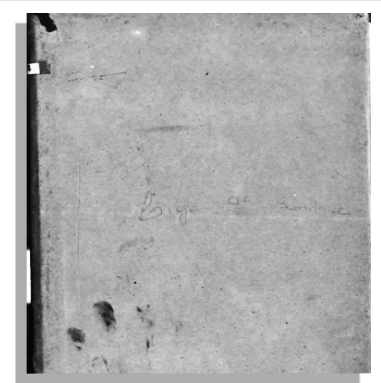

Figura I: Liga da Bondade EEB de Meleiro I953-1970

Descrição: Capa da Ata

Fonte: Arquivo da escola.

No conjunto das capas dos relatórios da Liga da Bondade, algumas delas são bastante enigmáticas. Enquanto que na EEB de Meleiro não foi criada nenhuma representaçáo para a capa de seus registros, na EEB Professor Lapagesse e na EEB Manoel Gomes Baltazar aparecem capas decoradas com desenhos e recortes, os quais, de algum modo, trazem implícitos os objetivos e finalidades da associação Liga da Bondade.

Nos relatórios da Liga da Bondade da EEB Professor Lapagesse, está claro o objetivo da Liga da Bondade, "[...] educar moralmente as crianças para que no futuro tivessem bom caráter e fossem honestas". Para tanto, representaram na capa dos seus registros um caminho decorado com rosas, remetendo-nos à ideia de que quando o(a) aluno(a) percorresse o caminho da bondade colheria bons frutos como amor, solidariedade e cooperação.

Já a capa do Relatório de I963, da escola EEB Manoel Gomes Baltazar é representado por uma imagem de duas crianças (menino e me- 


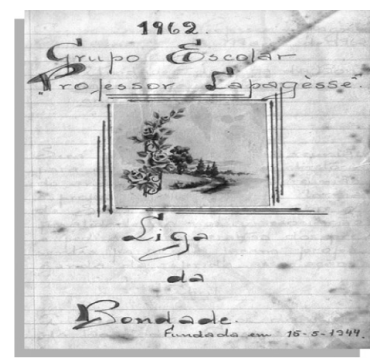

Figura 2: Capa do Relatório Liga da Bondade EEB Professor Lapagesse 1962-1966

Descrição: Caminho com flores

Fonte: Arquivo da escola.

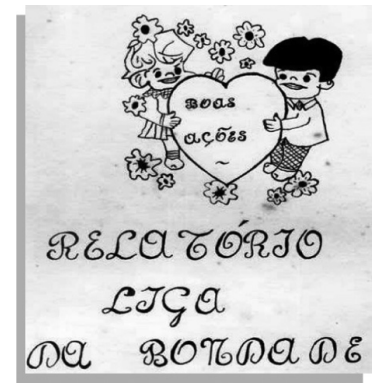

Figuraz: Capa do Relatório Liga da Bondade EEB Manoel Gomes Baltazar 1963

Descrição: Duas crianças segurando um coração com a inscrição "boas ações" Fonte: Arquivo da escola.

nina) segurando um coração que representa as boas ações. A imagem nos faz refletir sobre o forte intuito que a Liga da Bondade tinha em aguçar nas crianças o sentimento de pena, caridade e amor ao próximo.

Outra capa que faz pensar sobre a ideia de tentar estimular o sentimento de bondade e caridade em relação ao próximo é do relatório de 1967, da mesma escola. Ela traz uma criança colocando esmolas em um cesto.

O Relatório de 1969 traz em sua capa a imagem de crianças orando, chamando a atenção para a diversidade étnica ali representada. A primeira 


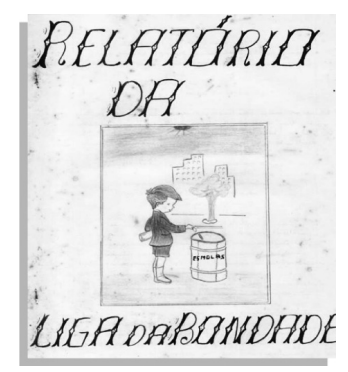

Figura 4: Capa do Relatório Liga da Bondade EEB Manoel Gomes Baltazar 1967

Descrição: Uma criança colocando esmolas em um cesto

Fonte: Arquivo da escola.

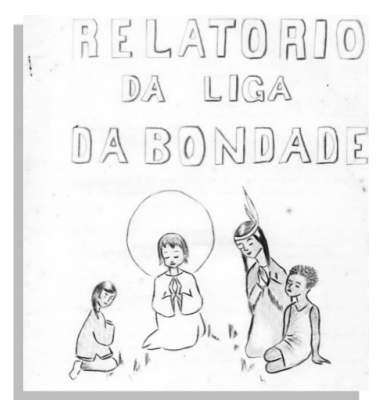

Figura 5: Capa do Relatório Liga da Bondade EEB Manoel Gomes Baltazar 1969

Descrição: Pessoas sentadas orando

Fonte: Arquivo da escola.

criança nos remete aos afrodescendentes, em função do seu cabelo "enroladinho" e a cor de sua pele. A segunda com um cocar de penas, lembrando os índios, a terceira representa os brancos e a quarta, devido às suas características físicas e o formato dos olhos, representa o povo asiático. Há indícios de que a criança de pele branca, por ter em volta de sua cabeça uma espécie de auréola, estaria representando um anjo, o que nos faz questionar: estaria ela ali para ajudar as outras crianças? As outras crianças estariam ali representando os mais necessitados? 


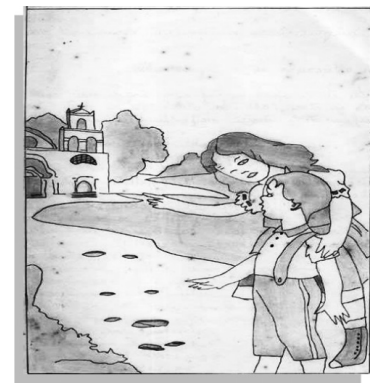

Figura 6: Capa do Relatório Liga da Bondade EEB Manoel Gomes Baltazar 1959

Descrição: Imagem de uma moça apontando o caminho da igreja a uma criança Fonte: Arquivo da escola.

A capa do Relatório de 1959 da EEB Manoel Gomes Baltazar traz a imagem de uma moça apontando o caminho da igreja para uma criança. Diante disso, posso inferir que os valores almejados pela Liga da Bondade eram reforçados pela Igreja Católica e vice-versa. Assim, é possível afirmar que atividades realizadas por esta associação tinham por finalidade atingir e abranger todos(as) da instituição nos assuntos religiosos, estimulando a fazerem parte do grupo de fiéis da Igreja Católica, tendo o conceito de bondade como âncora para todos os trabalhos.

Fica perceptível a forte influência da Igreja Católica no ambiente escolar, principalmente na EEB Manoel Gomes Baltazar, cuja coordenação do educandário era realizada pelas religiosas da Congregação de Santa Catarina, com forte influência do Frei Eusébio Ferreto ${ }^{3}$.

As marcas de uma educação religiosa nas capas da Liga da Bondade da escola EEB Manoel Gomes Baltazar remetem a uma reflexáo proposta por Moraes (2008). Para ele, a Igreja, para conservar a identidade e a legitimidade católica na sociedade, utilizou-se da educação para produzir bens simbólicos. Portanto, o intuito da Igreja Católica era propagar e difundir as suas práticas, a moral cristâ, conquistar mais adeptos e, de maneira simultânea, não permitir que os seus fiéis trocassem de religião.

A cordialidade do espírito de colaboração era outra questáo crucial. Na EEB de Meleiro, os sócios deveriam manter os princípios e bom comportamento em todos os lugares por onde estivessem e ainda deve- 
riam prestigiar aqueles que praticassem boas açóes. Nesse sentido, ressalvas eram feitas para acabar com as "briguinhas" entre os colegas. No ano de 1958, a entâo diretora da escola, Irmá Nívea Maria, diz que: "A Liga da Bondade é uma Associação disciplinada a formar o bom caráter da criança e ao bom caminho".

Nestas instituições havia formas de controlar as ações dos membros participantes e o monitoramento era uma delas. Dessa forma, era designado para cada classe um monitor, para que este registrasse, em uma caderneta fornecida pela associação Liga da Bondade, os acontecimentos diários e as boas açôes praticadas pelos colegas. Os monitores deveriam ter responsabilidade, de modo a exercerem um bom comportamento não só na escola, mas em todos os lugares por onde estivessem, para que assim servissem de exemplo aos colegas.

No entanto, os(as) alunos(as) que descumprissem as regras preestabelecidas pela Liga da Bondade seriam punidos(as). As puniçôes variavam de acordo com o nível da regra transgredida. Para tanto, eram dadas ressalvas aos bons conselhos, às palavras amigas, ao bom comportamento $\mathrm{e}$ ao bom exemplo. Além disso, os(as) alunos(as) expediam cartas para os membros da Liga da Bondade de outras escolas para compartilhar suas experiências.

Ao lançar um olhar mais criterioso sobre as atas da Liga da Bondade, percebe-se que eram aproveitadas datas comemorativas, tanto religiosas quanto civis, para desenvolver campanhas e arrecadar fundos para ajudar não só os necessitados, mas para manter a própria escola. Em relação às campanhas voltadas à escola, pode-se inferir que o governo estadual provavelmente não disponibilizasse recursos suficientes para a compra de materiais necessários para a realização das atividades pedagógicas. $\mathrm{O}$ quadro abaixo dá um demonstrativo destas atividades.

Inúmeras eram as campanhas, como mostra a tabela, mas o que chama a atenção é que não variava muito de escola para escola. Uma das campanhas que aparece invariavelmente no final do ano letivo era a Campanha do Natal dos Lázaros. Ao buscar nos registros bíblicos, encontramos a figura de Lázaro reproduzido em Lucas I6,19-3I, na parábola $O$ Rico e Lázaro. O Rico é representado por aquele que se veste de púrpura, aquele que passou toda a sua vida a se fartar esplendidamente, a desprezar os pobres. O Lázaro representa os excluídos da sociedade, é um homem 


\section{Tabela I: Campanhas desenvolvidas pela Liga da Bondade}

Campanha Natal

*Campanha das Missôes. dos Lázaros;

EEB MANOEL GOMES BALTAZAR 1959 - 1969

\begin{tabular}{|c|c|c|c|c|}
\hline 1959 & 1963 & 1967 & 1968 & 1969 \\
\hline $\begin{array}{l}\text { *Campanha Natal } \\
\text { dos Lázaros; } \\
{ }^{*} \text { Campanha das } \\
\text { Missóes. }\end{array}$ & $\begin{array}{l}\text { *Campanha } \\
\text { Missionária; } \\
\text { *Campanha Natal } \\
\text { dos Lázaros; } \\
\text { *Campanha } \\
\text { para compra de } \\
\text { brinquedos. }\end{array}$ & $\begin{array}{c}\text { *Colaboração } \\
\text { para o beneficio } \\
\text { da Associação da } \\
\text { Liga da Bondade } \\
\text { com bingos, rifas e } \\
\text { tetros; } \\
\text { *Campanha Natal } \\
\text { dos Lázaros. }\end{array}$ & $\begin{array}{l}\text { *Campanha de } \\
\text { roupas aos alunos } \\
\text { necessitados; } \\
\text { *Campanha para } \\
\text { merenda e festa } \\
\text { escolar; } \\
\text { *Campanha Natal } \\
\text { dos Lázaros; } \\
\text { *Campanha } \\
\text { para ajudar nas } \\
\text { despesas dos } \\
\text { tambores para o } \\
\text { desfile cívico. }\end{array}$ & $\begin{array}{l}\text { *Campanha do } \\
\text { material escolar; } \\
\text { *Campanha das } \\
\text { roupas usadas; } \\
{ }^{*} \text { Campanha para } \\
\text { merenda e festas; } \\
\text { *Campanha das } \\
\text { Missóes; } \\
\text { *Campanha do } \\
\text { dia das mães; } \\
\text { *Campanha do } \\
\text { dia das crianças. }\end{array}$ \\
\hline
\end{tabular}

EEB DE MELEIRO I953 - I970

\begin{tabular}{|c|c|c|c|c|}
\hline $1953-1954$ & $1955-1959$ & $1960-1962$ & $1963-1966$ & $1967-1970$ \\
\hline $\begin{array}{l}\text { *Campanha Natal } \\
\text { dos Lázaros; } \\
\text { *Organizaçáo de } \\
\text { rifa e um baile } \\
\text { em prol da casa } \\
\text { dos professores de } \\
\text { Santa Catarina. }\end{array}$ & $\begin{array}{c}\text { *Campanha de } \\
\text { rifas; } \\
\text { *Campanha da } \\
\text { garrafa e do ovo; } \\
\text { *Campanha Natal } \\
\text { dos Lázaros. }\end{array}$ & $\begin{array}{l}\text { *Campanha Natal } \\
\text { dos Lázaros e das } \\
\text { Santas Missóes; } \\
{ }^{*} \text { Campanha do } \\
\text { Selo; } \\
\text { *Campanha de } \\
\text { rifas e venda de } \\
\text { pirulitos e doces. }\end{array}$ & $\begin{array}{c}\text { *Campanha Natal } \\
\text { dos Lázaros e das } \\
\text { Santas Missóes; } \\
{ }^{*} \text { Campanha do } \\
\text { Selo. }\end{array}$ & $\begin{array}{c}\text { *Campanha de } \\
\text { agasalhos e roupas } \\
\text { usadas; } \\
\text { *Campanha Natal } \\
\text { dos Lázaros e das } \\
\text { Santas Missóes; } \\
\text { *Campanha do } \\
\text { lápis de cor; } \\
\text { *Campanha } \\
\text { de roupas/ } \\
\text { tecidos pretos } \\
\text { para confecção } \\
\text { de bermudas para } \\
\text { Educaçáo Física. }\end{array}$ \\
\hline
\end{tabular}

EEB PROFESSOR LAPAGESSE I962 - I966

\begin{tabular}{|c|c|c|c|c|}
\hline$\underline{1962}$ & $\underline{1963}$ & $\underline{1964}$ & $\underline{1965}$ & $\underline{1966}$ \\
\hline $\begin{array}{c}\text { *Campanha } \\
\text { de agasalhos, } \\
\text { calçados e roupas } \\
\text { usadas; } \\
\text { *Campanha de } \\
\text { uniformes. }\end{array}$ & $\begin{array}{c}{ }^{*} \text { Campanha de } \\
\text { agasalhos e roupas } \\
\text { usadas; } \\
{ }^{*} \text { Campanha do } \\
\text { Natal dos Lázaros. }\end{array}$ & $\begin{array}{c}{ }^{*} \text { Campanha de } \\
\text { agasalhos e roupas } \\
\text { usadas. }\end{array}$ & $\begin{array}{c}\text { *Campanha } \\
\text { de agasalhos, } \\
\text { calçados e roupas } \\
\text { usadas; } \\
{ }^{*} \text { Campanha para } \\
\text { arrecadaçáo de } \\
\text { donativos; } \\
\text { *Campanha do } \\
\text { Natal dos Lázaros; } \\
\text { *Campanha das } \\
\text { Missóes. }\end{array}$ & $\begin{array}{l}\text { * Náo constam } \\
\text { registros de } \\
\text { campanhas no } \\
\text { referido ano. }\end{array}$ \\
\hline
\end{tabular}

Fonte: Dados coletados a partir dos registros das Atas da Escola 
pobre e leproso. Assim deduz-se que o nome Campanha dos Lázaros seja referente a este personagem bíblico. (BÍBLIA, 1973).

Diante das campanhas e, principalmente, da Campanha do Natal dos Lázaros, pode-se afirmar que as ligas analisadas seguiam rigorosamente as prescrições apontadas no Decreto n. ${ }^{0} 3.735 / 46$ do Estado de Santa Catarina. Além disso, intencionavam construir um sujeito com espírito caridoso, fazendo com que as atitudes de cada aluno(a) participante fossem voltadas para os mais necessitados e para a própria sociedade.

Para tanto, o Estado volta-se para a Liga da Bondade mais precisamente através do Decreto-Lei n. ${ }^{\circ} 3.735 / 46$, art. $576 \leqq \mathrm{I}^{\circ}, 2^{\circ}, 6^{\circ}, 7^{\circ}$ e $8^{\circ}$, o qual faz prescriçóes oficiais para determinar as finalidades da referida associação:

$\$$ I $^{\mathrm{o}}$ Tinha por intuito inculcar nos(as) alunos(as) bons hábitos e virtudes;

$\$ 2^{\circ}$ Retrata a escolha dos(as) alunos(as) que poderiam ingressar na Liga da Bondade, sendo exemplo para os demais colegas;

$\$ 6^{\circ}$ e $\$ 7^{\circ}$ Descrevem o comportamento que os(as) alunos(as) teriam que possuir;

$\$ 8^{\circ}$ Não poderia ingressar na Liga da Bondade aqueles que possuíssem "maus costumes" (SANTA CATARINA, I947).

É explícita a intenção da Liga da Bondade de formar cidadãos com caráter virtuoso, boa conduta, disciplinados, com espírito solidário. O espírito caridoso é algo almejado pela Igreja Católica, pois é um indicativo de princípios morais e uma prática representativa da boa essência do ser humano. Desse modo, vê-se a pretensão em torno da caridade, expor à sociedade um caráter nobre, bondoso, tendo como princípio básico o amor, para que homens e mulheres se constituam a partir das virtudes da bondade, humildade e perdão.

\section{Consideraçóes finais}

No cenário da Campanha de Nacionalização, instituída no Estado Novo, foram implantadas as associaçóes auxiliares da escola, entre elas 
estava a Liga da Bondade. As associaçóes foram criadas pela legislação educacional catarinense de acordo com as disposiçóes nacionais, formando grupos estabelecidos nas escolas primárias, com o intuito de socializar os alunos por meio de aprendizados relacionados à civilidade e à moral.

Nos registros encontrados sobre as Ligas da Bondade, nas três escolas públicas estaduais abarcadas neste estudo, "pouco" aparece sobre nacionalismo e patriotismo, porém lhes é perceptível nas entrelinhas dos registros. As marcas da educação religiosa também estão bem presentes, tanto no conteúdo das anotaçóes como nas próprias capas dos relatórios.

Chama a atenção as capas dos relatórios da Liga da Bondade da escola EEB Manoel Gomes Baltazar, levando-nos a pensar sobre o papel da escola na conservação da identidade e da legitimidade católica daquela comunidade escolar. Posso inferir que a escola tornou-se um local onde a prática pedagógica ensinava os símbolos católicos, práticas e reflexóes de devoção ao catolicismo, com o intuito de propagar e difundir suas práticas, a moral cristã, conquistar mais adeptos e, de maneira simultânea, não permitir que seus fiéis trocassem de religião.

Seus sócios deveriam se envolver em boas açóes voltadas para os mais necessitados, bem como atividades que a Igreja organizava. A partir destas açóes torna-se notável o intuito e finalidades da Liga da Bondade: moldar sujeitos civilizados e educados, necessários para aquele tipo de sociedade. Igreja e Estado parecem caminhar juntas, mesmo que a constituição republicana tenha homologado que o Estado deveria ser laico. $\mathrm{Na}$ prática, Igreja e Estado continuaram juntos, prova disso são as Ligas da Bondade, que pretendiam moldar comportamentos e formar sujeitos virtuosos e caridosos.

\section{Notas}

1 O projeto do Cemessc foi aprovado por meio do Edital MCT/CNPq no 42/2007 - Difusão e Popularização da C\&T.

2 Reforma Trindade (1935) foi uma reforma do ensino que tinha por intuito remodelar o sistema de ensino reformulando sua estrutura e organização, atuando na propagação de uma nova prática pedagógica, especialmente, a partir da organização dos eventos de formação continuada para professores. A mesma reorganizou o Departamento de Éducação do Estado tornando-o núcleo de discussão para o campo.

3 Frei Eusébio Ferreto (I956 a I973): primeiro padre da paróquia de Nossa 
Senhora da Conceição de Maracajá, pertencente à Ordem dos Freis Capuchinhos, envolveu-se veementemente com os inúmeros problemas da comunidade, especialmente na área da educação (MORAES, 2008, p. I24).

\section{Referências}

ANDRADE, Maria da Conceição Lima de. et al. A Liga de Bondade: um estudo sobre o conformismo coletivo na escola. In: $27^{\text {a }}$ REUNIÁO ANUAL DA ANPED, 2004, Caxambu, MG. Sociedade, democracia e educação: qual universidade?, 2004. v. o. p. I-IO. Disponível em: <http://27reuniao.anped.org.br/gti4/pi 43.pdf> Acesso em I9 abr. 2OII.

BÍBLIA: Novo Testamento. São Paulo: Paulinas, I973. 722 p.

BEIRITH, Ângela. As escolas isoladas de Florianópolis no contexto da regulamentação do ensino primário (1946 - I956). Revista Linhas: Revista do Programa de PósGraduação em Educação da Universidade do Estado de Santa Catarina, Florianópolis, v. IO, n. 2, p. I56-I68, jul./dez. 2009.

CHARTIER, Roger. Textos, impressóes, leituras. In: HUNT, Lynn. A nova história cultural. São Paulo: Martins Fontes, 1992.

CUNHA, Maria Teresa Santos. Civilidade em Textos: Estudo sobre um jornal manuscrito infantil (1945-I952). Faed/Udesc, 2010.

EEB MANOEL GOMES BALTAZAR. Ata da Liga da Bondade. Maracajá, SC, I959. Manuscrito.

EEB MANOEL GOMES BALTAZAR. Ata da Liga da Bondade. Maracajá, SC, I959-1963. Manuscrito.

EEB MANOEL GOMES BALTAZAR. Ata da Liga da Bondade. Maracajá, SC, I959-1967. Manuscrito.

EEB MANOEL GOMES BALTAZAR. Ata da Liga da Bondade. Maracajá, SC, I959-I968. Manuscrito.

EEB MANOEL GOMES BALTAZAR. Ata da Liga da Bondade. Maracajá, SC, I969. Manuscrito.

. Histórico da Escola. Maracajá, SC, [19--]. Manuscrito.

EEB DE MELEIRO. Ata da Liga da Bondade. Meleiro, SC, I953-I970. Manuscrito. . Histórico da Escola. Meleiro, SC, [19--]. Manuscrito.

EEB PROFESSOR LAPAGESSE. Ata da Liga da Bondade. Criciúma, SC, I962-1966. Manuscrito. 
. Histórico da Escola. Criciúma, SC, [19--]. Manuscrito.

ELIAS, Norbert. O processo civilizador. Rio de Janeiro: Jorge Zahar, I993. 307 p.

JULIA, Dominique. A Cultura como Objeto Histórico. Tradução Gizele Souza. Revista Brasileira de História da Educaçâo, n. I, p. 09-43, jan./jun. 2001.

LOUSADA, Isabel. Ligas de Bondade. Repositório Universidade Nova: Centro de Estudos de Sociologia da Faculdade de Ciências Sociais e Humanas da Universidade Nova, Lisboa, v. I, p. I8-20, 20I0. Disponível em: <http://run.unl.pt/ handle/I0362/4302> Acesso em: I8 abr. $201 \mathrm{I}$.

MARTINSON, Célia Carmem. Institucionalização da escola pública em área ruralJoaçaba - SC (1938-1961). 2009. I 44 f. Tese (Doutorado em Educação) - Unidade Acadêmica de Pesquisa e Pós Graduação, Unisinos, São Leopoldo (RS), 2009.

MORAES, Lucio Vânio. Memória escolar e campo religioso: Identidade e imaginário católico na Escola de Educação Básica Manoel Gomes Baltazar em Maracajá - SC (I959 - I976). 2008. 259 f. Dissertaçáo (Mestrado em Educação) - Universidade do Extremo Sul Catarinense, Criciúma, 2008.

SANTA CATARINA. Procedência Governamental. Lei n. ${ }^{\circ}$ 40, de 12 de dezembro de 1947. Cria cargo no Quadro Único do Estado e da outras providências.

Florianópolis, 1947. Disponível em: http://www.carapicu.alesc.sc.gov.br/ALESC/ DOCS/I947/40_1947_Lei.doc> Acesso em: 28 set. 201 I.

Secretaria da Justiça, Educação e Saúde. Departamento de Educaçáo. Decreto

Recebido em Io mar. 2013 / Aprovado em 29 out. 2013

Para referenciar este texto

NIEHUES, M. R.; RABELO, G. As regras de civilidade prescritas pelas Ligas da Bondade nas escolas públicas estaduais do sul de Santa Catarina (1953-1970). EccoS,

São Paulo, n. 32, p. 157-I78. set/dez. 2013. de ensino primário no Estado de Santa Catarina. Florianópolis, I947.

SILVA, Fabiany de Cássia Tavares. Cultura escolar: quadro conceitual e possibilidade de pesquisa. Educar: Revista da UFPR, Curitiba, n. 28, p. 20I-216, 2006.

SILVA, Mônica Ribeiro. Reformas educacionais e cultura escolar: A apropriação dos dispositivos normativos pelas escolas. Caderno de Educação: Revista da FaE/PPGE/ UFPel, Pelotas, n. 32, p. I23-I39, jan./abr. 2009.

ZEN, Mariane Werner. Brasileiros pelas letras: a ação educativa presente nos clubes de leitura e bibliotecas escolares de Santa Catarina. O caso do Grupo Escolar Alberto Torres, Brusque, SC (I938-I950). 2007. I 44 f. Dissertação (Mestrado em Educação) Universidade do Estado de Santa Catarina, Florianópolis, 2007.

$n .^{\circ} 3735$, de 17 de dezembro de 1946. Estabelece o regulamento para os estabelecimentos 